\title{
THE EUROPEAN UNION'S COMMON AGRICULTURAL POLICY AS AN INSTRUMENT OF EQUALIZING FARMS' INCOME
}

\author{
Piotr Golasa ${ }^{1}, \mathrm{PhD}$ \\ ${ }^{1}$ Warsaw University of Life Sciences (SGGW), Faculty of Economic
}

\begin{abstract}
The main objective of this article is to find out the level of farming income differences and the influence of particular CAP instruments on these income differences. The first part of the thesis presents theoretical aspects of the redistribution function performed by the state and the most important elements of this function under the Common Agricultural Policy. The second part reveals the level of farmers' income in 2014 and its differences, which were found out based on a survey done in a group of 573 Polish farmers. The income was computed in accordance with the profit and loss account used in the FADN system. The Gini coefficient was applied to find out the level of income inequality. It was concluded that the CAP instruments play an active role in supporting the level of income and eliminating income differences among farmers, which was proved by calculating the Gini coefficient. Without the CAP support instruments, it amounted to 0.745 , and after applying them - 0.689. The share of support in the income accounted for $41.6 \%$. Without the CAP instruments, only $40 \%$ of the surveyed households gained income from their activity.
\end{abstract}

Key words: income differences, Gini coefficient.

JEL code: E62

\section{Introduction}

After Poland entered the European Union (EU), the domestic agriculture underwent deep changes concerning economic and legal conditions, which resulted from the fact that the country was also included in the Common Agricultural Policy (CAP). On the one hand, it brought many various EU's funds (area payments, investment support, environmental payments etc.), on the other, farmers had to fulfil various requirements and administrative obligations. A serious socialeconomic problem arose. Not all the farmers equally benefited from the opportunities that appeared after Poland's accession to the EU. This caused a long-lasting material disparity of this social group. Additionally, it was indicated more and more often that because of the system of area payments, which was separated from output, the CAP advantaged large farms, gaining high profits anyway. The situation of investment programmes looks similarly. They are mainly addressed to efficiently managed, developing farms, which are required to have an appropriate level of income if they are to vote funds for investment on its first stage (a part of the funds is reimbursed later). Thus, some theoretical problems appear here: should a state (or the EU as a whole) influence income differences among farmers, are the CAP instruments successful in their redistribution role?

The state's redistribution function is one of the three classic functions (together with stabilization and allocation) mentioned in the economic theory. P. A. Samuelson and W. D. Nordhaus define it as supporting justice by means of taxes and programmes of expenses to redistribute incomes to selected groups of people (Samuelson P.A., Nordhaus W.D. 2004). This function arouses the most controversy among economists because it consists in such an adjustment of income distribution which matches what the society considers to be the appropriate or fair distribution (Musgrave R.A., Musgrave P.B., 1989). Thus, this function means one social group's benefits at the cost of other groups. That is why numerous doubts emerge here. They concern such issues as a state's function scope, redistribution influence on an economy efficiency, or the criteria of social justice assessment. These discussions are covered by the theory of welfare economics. It focuses on defining the criteria of social choice, the ways of taking decisions in a society, and the assessment of the work of such institutions as state or market. Theoretical discussions on this matter concern performing state functions, the redistribution function and its 
specific kind related to state interventionism in agriculture. Studies in this respect have received great recognition: in 2015 Angus Deaton was awarded the Noble Prize in economics for his analyses of consumption, poverty, and welfare. This economist had a great influence on the research on social and income disparities. He created one of the formal presentations of the Gini coefficient (Deaton A., 1997).

That is why the main objective of this article is to find out the influence of the CAP subsidies for production and investments on the level of farms' income and its diversity.

To achieve this goal, the following research tasks were set:

- characterizing the CAP production and investment subsidies based on the Rural Development Programme for 2007-2013,

- finding the level of the examined farms' income,

- finding out how much the examined farms' income is diversified.

In this study, a hypothesis was assumed that the current CAP support system deepens farmers' income differences.

The object of the study covered 573 farmers of Masovian, Lublin, Podlaskie and Lodz Voivodeship, who ran farms on their own. In the study, the author used data gathered in his own survey. The survey was run during trainings for farmers which concerned a farm's accounting. The data gathered are related to farmers' income in 2014. The income was computed in accordance with the profit and loss account used in the FADN system. The calculations covered:

I. Output value:

1. (-) Intermediate consumption,

2. (+) Balance of subsidies and taxes,

a. (+) Operational activity subsidies,

b. (-) Taxes,

c. (+) Operational activity VAT balance;

II. Gross value added:

1. (-) Costs of external factors,

2. (+) Balance of investment subsidies and taxes,

a. (+) Investment subsidies,

b. (+) Investment activity VAT balance;

III. Family farm income (FADN, 2016).

In this study, operational activity subsidies included direct, LFA and agri-environmental payments. The Lorenz curve and the Gini coefficient, related with it, were applied to find out the level of income inequality. This method is widely used in case of investigating income disparities all over the world (Thewissen et al., 2015). The curve presents cumulated percentage of income which falls for subsequent farms, ordered from the richest to the poorest ones. When the incomes of all the farms are equal, the Lorenz curve is a straight line inclined at an angle of 45 degrees against $\mathrm{X}$-axis (perfect equality line). While inequality grows, the Lorenz curve deviates more from the perfect equality line. The Gini coefficient is the quantity metric of this inequality, and it amounts to the doubled area between the real curve and the perfect equality line (Samuelson P.A., Nordhaus W.D., 2004). The following formula presents one of the formal approaches:

$$
G=\frac{1}{2 \mu n^{2}} \sum_{i=1}^{n} \sum_{j=1}^{n}\left|x_{i}-x_{j}\right|
$$


where:

$\mu$ - average income

n - sample population (Kot S.M., 2002).

The Gini coefficient takes the values from 0 (in case of the perfect equality of incomes) to 1 (when one farm has all the income). This coefficient fulfils the postulate of Pigou-Dalton transfer (which in case of farms means that with income transfer from farms with a higher income to those with a lower income, it changes), symmetry, homogeneity, and replica. Yet it does not fulfil the decomposition postulate (Lissowski, et al. 2008).

\section{Research results and discussion Instruments of support for farms' income}

In 2014, although theoretically there was a new financial framework of the EU for 2014-2020, the system of support for agriculture had not been significantly changed as compared to the previous years. As part of direct payments, farmers received:

- single area payment (910.87 PLN/ha),

- separate payments for: tomatoes, soft fruit, sugar,

- specific support: for cows, for sheep, specific area payments for legumes and leguminous fodder crops, for high quality raw tobacco,

- transitional state measures: decoupled payment for hop, decoupled payment for potato starch, decoupled payment for tobacco (Ministry of Agriculture and Rural Development, 2014).

Apart from that, payments were given to farmers from less favoured areas (LFA). The rates amounted to:

- mountain areas (mountain LFA) - 450 PLN/ha;

- lowland areas (lowland LFA):

$\circ$ : lowland LFA I - 179 PLN/ha;

○ : lowland LFA II - 264 PLN/ha;

- specific areas (specific LFA) - 264 PLN/ha.

Degressivity was set for LFA because a farmer can receive:

- from 1 to 50 ha - $100 \%$ of payments;

- from 50.01 to 100 ha - 50 \% of payments;

- from 100.01 to 300 ha - $25 \%$ of payments;

- over 300 ha - payment is not granted.

Farmers who decided to take additional obligations could enter an agri-environmental programme. It consisted in undertaking to fulfil a 5-year obligation as regards one of several actions. They included: sustainable agriculture, organic farming, extensive grassland, protection of endangered bird species and natural habitats, conservation of endangered genetic resources, soil and water protection, buffer zones. The level of payment was computed as the product of: a rate per hectare and the area of farming plots, or a rate per animal and the number of cows, mares, sows, and ewes, or a rate per metre of balk and the length of this balk.

As part of the Rural Development Programme for 2007-2013, which was still binding in 2014, one could receive support for investments in a farm. The action "Farms' Modernization" played the main role here. The aid consisted in reimbursing 40-60\% of the eligible costs of the investment whose objective was to improve a farm's overall results, increase gross value added or improve a 
farm's situation as regards environmental protection (Ministry of Agriculture and Rural Development, 2013).

\section{Research results}

The average area of the surveyed farms amounted to 25 ha, out of which the vast majority was farmland (22.1 ha). Most surveyed farms dealt with both crop and livestock production. More than a half of a farm's output fell for crop production (52\%), livestock production accounted for $46 \%$ (Figure 1).

Source: the author's own work

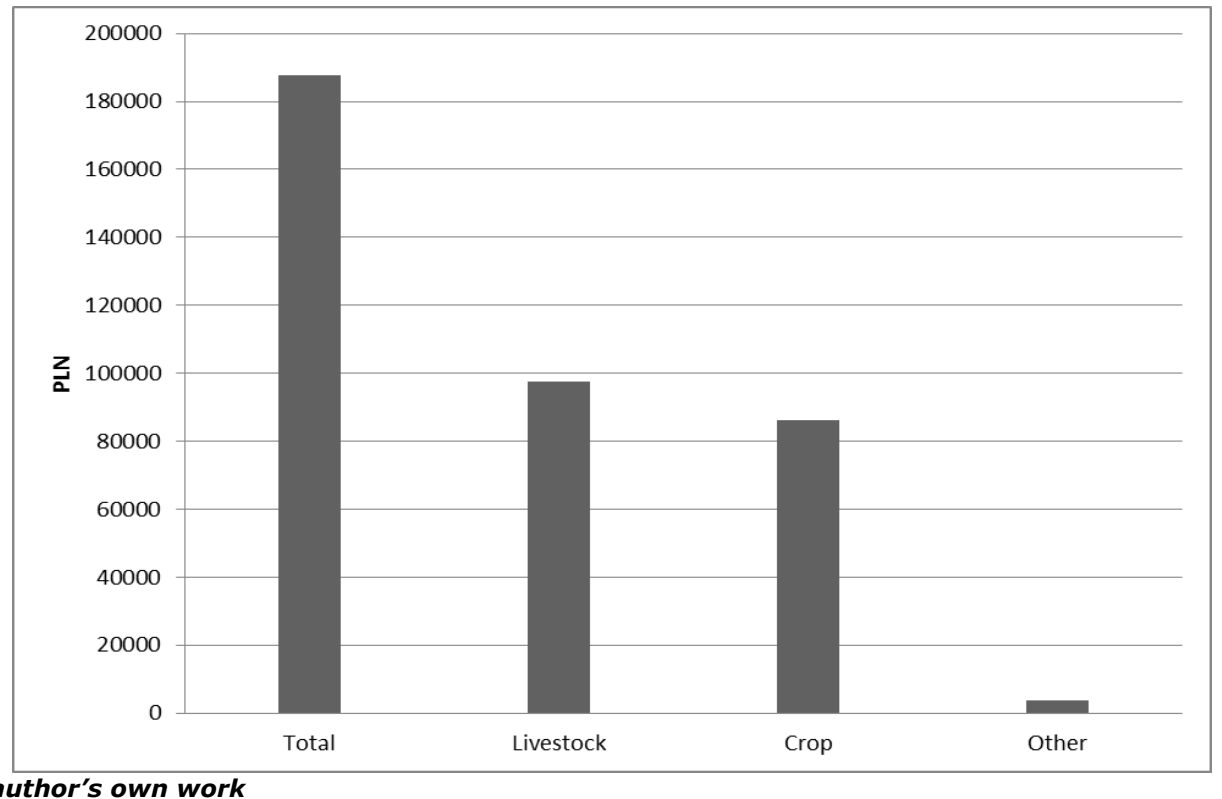

Fig. 1. Output value in the surveyed farms

A small part of farms dealt with another kind of production, but its value was marginal. The average output value in a farm amounted to PLN 187.622, which was PLN 7.505 per hectare.

In 2014, the average level of farming income amounted to PLN 64.791, which translated into 2.544 PLN/ha of a farm's area. It should be underlined that area and environmental payments had a considerable influence on incomes. Almost all farms received this kind of support (95\%), which is strictly connected to the easy access and application process (Pietrzykowski R., Wicki L., 2011), and it accounted for 1/3 of incomes. It amounted on average to PLN 21.123 per farm. On average, PLN 1.074 of payment fell for each hectare of a farm's area. The situation is totally different as regards investment subsidies.

The special character of investment subsidies is related to the fact that a farmer needs to be highly active in the process of applying for it and fulfil a series of formal and administrative requirements. A large part of the interested people, gave up participating in this action after they gained all the information on formal requirements (Borawski P., Brodzinski Z., 2014). In the surveyed group, fewer than $6 \%$ of farmers went through the whole process to finally get this kind of support. That is why in spite of a great significance of these funds to farming and rural development (Bienkowska-Golasa W., 2015), they are not commonly used. On the other hand, benefits gained by the applying farms were very high, on average - PLN 50.536, which accounted for nearly $2 / 3$ of these farms' income.

Area, environmental and investment payments had a huge influence on the level of income. Without these support instruments, $40 \%$ of the surveyed farms do not have any income (with 
payments $-23 \%$ ), and this aid is responsible for $42 \%$ of the income gained. It was also recorded that these instruments had a visible impact on income differences. The Lorenz curve showing this phenomenon is as follows.

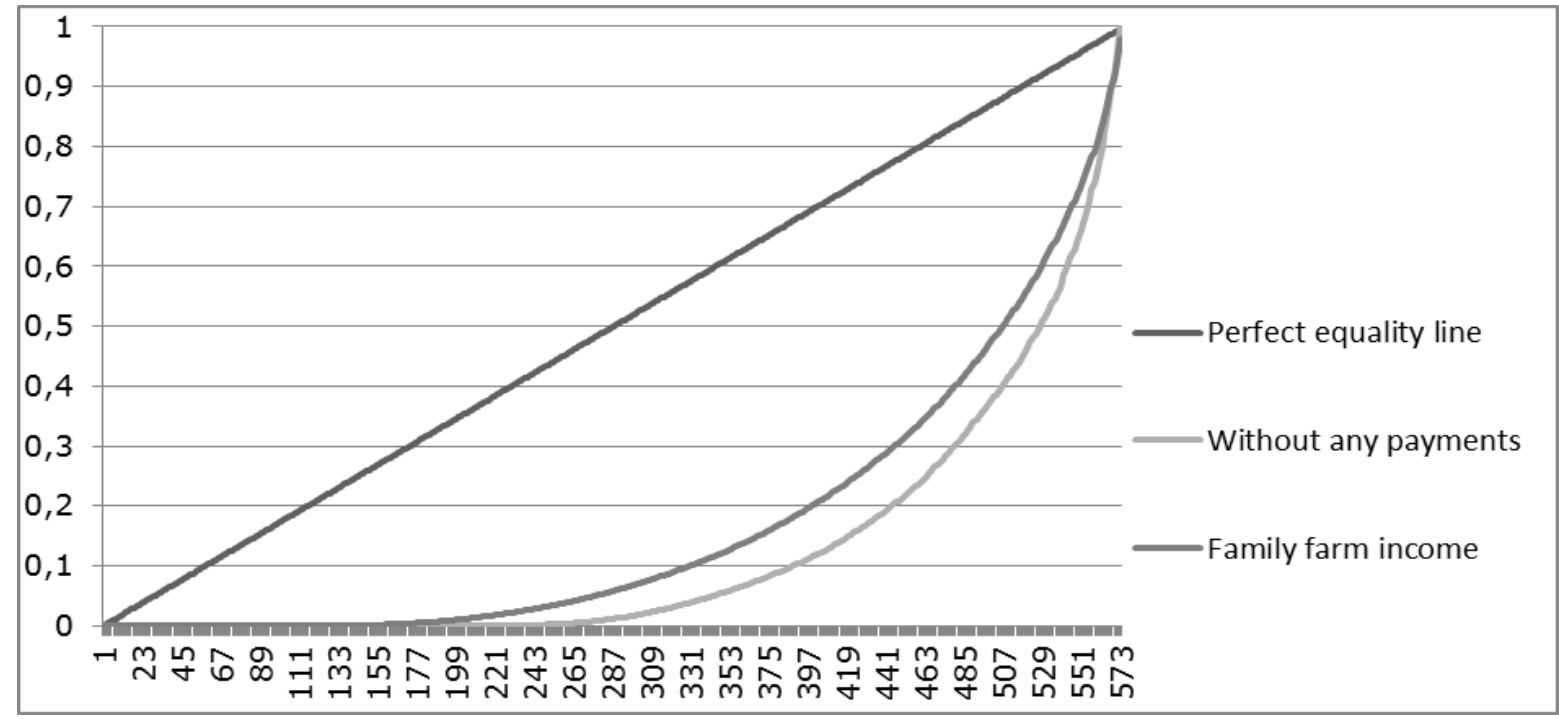

Source: the author's own work

Fig. 2. The Lorenz curve for farms' incomes with area and environmental payments, and investment subsidies, as well as without this aid

The Lorenz curve for farming incomes is closer to the perfect equality line than the curve for incomes without area, environmental and investment payments. This means that these instruments have the redistribution function and they reduce income differences among the surveyed farms. It is confirmed by the Gini coefficient values (Figure 3 ).

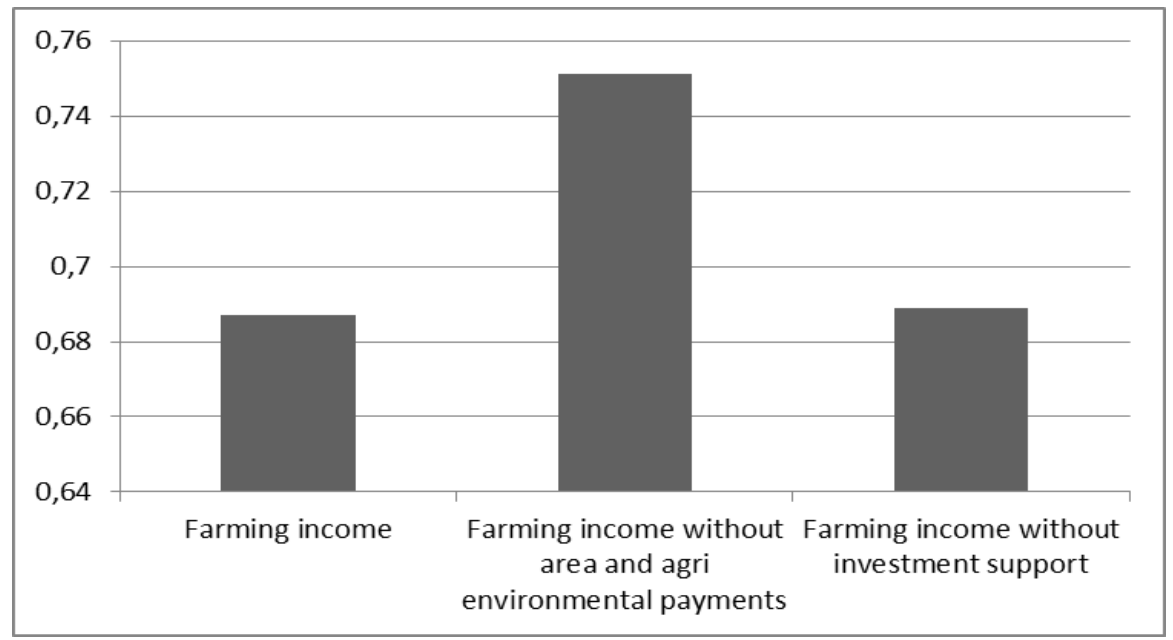

Source: the author's own work

Fig. 3. Gini coefficient values for farming incomes

The Gini coefficient value at the level of more than 0.5 reveals great differences in a given characteristic. It amounts to 0.687 for farming incomes. In case of farming income without area, agri-environmental and investment payments, it has a higher value than farming income calculated with this support. Hence, thanks to these instruments, farmers' incomes are being levelled. However, the aid influence has a different power. While area and environmental payments have a significant influence (the Gini coefficient changes from 0.751 to 0.687 ), investment subsidies are of marginal importance (change from 0.689 to 0.687 ). It depends on how commonly particular support instruments are used. 


\section{Conclusions, proposals, recommendations}

The research makes it possible to draw the following conclusions.

1) The research hypothesis was rejected. Investment subsidies, and area and environmental payments result in lowering income differences. Area and environmental payments are of the greatest importance here. The influence of investment subsidies on levelling incomes is practically non-visible, but they definitely do not cause the increase of income differences.

2) Area and environmental payments have a huge influence on farms' income. Over $95 \%$ of farms benefit from this kind of support and in 2014, it accounted for $1 / 3$ of income.

3 ) Investment aid is not so significant and widespread as area and environmental payments. Only $6 \%$ of farmers benefited from this kind of support. However, for those who did, these funds were important because they accounted for $64.24 \%$ of the income.

The discussion on what the CAP should be like after 2020 is slowly starting. It should cover not only the issues concerning income aid for farmers but also equalizing the income among farmers. There are huge disparities in farmers' incomes, which is typical for this kind of activity. There are small family farms and large professional farming companies. Income support instruments have an influence on all of them. That is why it is essential that these CAP instruments be developed appropriately so that they will not deepen the current income differences. It seems that a good system of area payments with degressivity after exceeding a defined threshold of payments is the best instrument which performs this task. This can prevent payment concentration in the largest farms, because the largest and richest farmers could receive only a fixed maximum amount of payment.

\section{Bibliography}

1. Bienkowska-Golasa, W. (2015). Entrepreneurship and Trends in Development of Rural Communes in Poland, Jelgava, Economic Science, Economic Science for Rural Development, RURAL DEVELOPMENT AND ENTREPRENEURSHIP, No 39, pp 227-235.

2. Borawski P., Brodzinski Z., (2014). Wykorzystanie wsparcia finansowego z Unii Europejskiej w gospodarstwach mlecznych w opinii ich wlascicieli (Using Financial Aid from the European Union by Milk Farms in their Owners' Opinions), In: ROCZNIKI NAUKOWE EKONOMII ROLNICTWA I ROZWOJU OBSZAROW WIEJSKICH, Volume 101, no.1.

3. Deaton, A. (1997). The Analysis of Household Surveys. Baltimore and London: The John Hopkins University Press, p. 139.

4. FADN (2016). Wyniki Standardowe 2012 uzyskane przez gospodarstwa rolne uczestniczace w Polskim FADN, Czesc 1, Wyniki standardowe (2012 Standard Results of Farms Participating in Polish FADN, Part I. Standard Results), Warsaw: IERIGZ-PIB.

5. Kot S.M. (2002). Metodologiczne dylematy pomiaru nierownosci dobrobytu (Methodological Dilemmas of Welfare Inequality Measurement), In: Conference materials: Nierownosci Spoleczne a Wzrost Gospodarczy (Social Disparities versus Economic Growth), Rzeszow.

6. Lissowski G., Haman J., Jasinski M. (2008). Podstawy statystyki dla socjologow (The Basics of Statistics for Sociologists). Warsaw: Wydawnictwo Naukowe Scholar.

7. Ministry of Agriculture and Rural Development, (2013). Rural Development Programme for 2007-2013.

8. Musgrave, R. A., Musgrave, P. B. (1989). Public Finance in Theory and Practice, New York: McGraw-Hill, p.6.

9. Pietrzykowski R., Wicki L., (2011). Regional Differentiation in Uptaking the CAP Funds on Agri-environmental Programmes in Poland, Jelgava, Economic Science for Rural Development, SUSTAINABILITY, Issue: 26. pp. 149-162.

10. Regulation of the Minister of Agriculture and Rural Development of 7 November 2014 On the Rate of Single Area Payment for 2014. (Dz. U. (Journal of Laws) 2014, item 1602).

11. Samuelson P. A., Nordhaus W. D. (2004). Economics V. 2. Warsaw: PWN, p. 71.

12. Thewisse S., Kenworthy L., Nolan B., Roser M., Smeeding T., (2015). Rising Income Inequality and Living Standards in OECD Countries: How Does the Middle Fare? (No. 656). LIS Working Paper Series. 